\title{
AIDS and the private sector
}

\author{
It will take more than awareness to slow the HIV pandemic in Africa.
}

Tris his week, the rock star Bono and a host of other celebrities are promoting the US launch of 'Product Red', the private sector's campaign to fight AIDS. Some of the profits on products sold in this initiative, as agreed by their manufacturers, will go to the Global Fund to Fight AIDS, Tuberculosis and Malaria, specifically to confront AIDS in Africa. The arrival of iPods, phones and clothing that will highlight the AIDS pandemic and provide financial support for the global fund is to be welcomed.

The publicity surrounding the US launch - which follows a similar process earlier this year in Britain - may convey the impression that large global corporations are at the forefront of the fight against AIDS. But a closer look at the situation reveals that this is rarely the case (see page 738).

For two decades, AIDS activists and officials have implored the private sector to join the fight against AIDS. In reality, that effort remains overwhelmingly dependent on public funding and public officials. In all but a few cases, the private sector has been a minor player. The Product Red campaign is one sign that this may finally be changing - but much more needs to be done.

To be fair, the drug industry, often in partnership with major economic players such as oil companies, is actively involved in research, diagnostics, counselling and treatment in places where the pandemic is most severe. Other large corporations - such as mining company Anglo American and the brewer Heineken - provide highquality monitoring and treatment programmes for their employees and, sometimes, for their families.

But for reasons of treatment cost and the scale of effort required, these initiatives have taken a long time to get going. Private companies must urgently be encouraged to increase their efforts to take some of the load off governments.

What's more, employers' responses to the pandemic need to reach beyond the provision of medical assistance. Some of the responses needed are more obvious than others. For example, cement company
LaFarge is changing its transport logistics to avoid having several hundred African truck drivers sitting outside its plants for hours or even days at a time awaiting delivery. A more general problem that needs to be discussed and confronted is the web of sexual relationships that exists within some companies.

There are professional skills in the private sector that have not been significantly tapped. In their enlightened self-interest, private companies could be working with governments to apply their expertise in large-scale logistics and financial management to the mammoth task of constraining the epidemic. But even where money is theoretically available, there are bottlenecks. In the Ivory Coast, for example, a Merck scientist called on the company's internal financial expertise to help unclog some issues with resource allocation, only to be told that it would take eight months.

There are many other impediments to private-sector engagement, particularly AIDS politics and suspicion among public officials and at nongovernmental organizations. Business "Private companies must be encouraged to increase their efforts to take some of the load off governments." expertise would be more readily brought to bear on the pandemic if public-health officials and other parties could agree among themselves what administrative actions need to be taken to fight AIDS.

Nevertheless, such actions are being identified in many hard-hit countries, and corporations and their skills are sometimes being harnessed to implement them. Some of those involved in Product Red, such as the clothing retailer Gap, already lead by example at their own factories in Africa.

Yet there is a nagging concern among AIDS officials that global attention may be drifting away from the pandemic, at a time when the need to confront it aggressively has never been greater. Businesses, not just in Africa but elsewhere, need to be planning for the battle now, so they can act before it is too late.

\section{Striving for excellence}

\section{A German exercise to foster élite universities began inauspiciously but is a step in the right direction.}

$T$ he German economy, along with the nation's self-esteem, has been staging a recovery of late after a long period of stagnation. Science seems to be enjoying a parallel renaissance. But structural changes are essential if the country's research system is to remain internationally competitive.

Science has long held a prominent place in German society. However, its institutions and practitioners have sometimes been slow to adapt to changing circumstances - notably the rapid emergence of biotechnology and molecular medicine, the increased internationalization of science, and the desire of many scientists to be involved in the commercialization of their work.

Nonetheless, the German government has continued to steadily increase its investment in science. Germany has benefited immensely from an influx of scientific talent from central and eastern Europe. And efforts have been undertaken to reverse the brain drain of scientists from Germany, with several initiatives aimed at bringing researchers home from the United States.

The main concern is the weakness of Germany's top universities relative to their rivals abroad. Germany's rigid federal structure and its tendency to treat all its universities on an equal basis have contributed to a situation in which no German research university has established itself in the top global tier. According to a survey by the 
Shanghai Jiao Tong University, for example, no German university is among the world's top 50 .

The government has responded to this challenge with an 'excellence initiative' that will reward universities with particularly convincing concepts in collaborative research and postgraduate training. The first winners were announced on 13 October, and the outcome disproves fears that political considerations might have influenced the selection.

But even if the initiative succeeds on its own terms, it will not in itself provide sufficient resources to propel the winners into the top tier of global universities. Nor will it remove the structural problems, such as the bickering between the states and the federal government over science and education, that prevent German universities from playing to their strengths.

Nonetheless, the initiative shows that Angela Merkel's coalition government is aware of the need for university reform. At the very least, it gives a handful of universities, institutes and research groups the opportunity to showcase their strengths, and provides a tidy sum of money to improve their standing further.

Additionally, the competition has forced every university to think hard about its strengths and weaknesses. For winners and losers alike, this will help them nurture promising areas of research and develop necessary collaborations across disciplines. It has injected a palpable spirit of optimism, and a healthy extra shot of competition, into the research system.

The selection of the winners on 13 October nearly became a spectacular failure when some politicians, who felt ignored by the scientific jury, allegedly threatened to call the whole thing off. In the end only three universities made the cut - the Ludwig Maximilians University Munich, the Technical University of Munich and the Technical University of Karlsruhe - rather than the expected five. But the fact that some departments in less prominent universities, such as Würzburg or Bremen, gave the winners a run for their money should be an incentive to those who lost out this time to sharpen their research profiles.

Germany's coalition government and those of its 16 states must continue to coordinate their efforts to develop the universities. There are strong indications on the ground that the dominance of the traditional, all-powerful 'Herr Professor' is fading on German campuses, to be replaced by younger laboratory chiefs with a more progressive outlook on how science should be done. That, too, augers well for the future of science at German universities.

\section{A state of flux}

\section{A fresh start beckons for the politics of US science.}

\footnotetext{
$T$
}

he United States is approaching a potential turning point for many disgruntled scientists. On 7 November, voters will go to the polls to elect most of their congressional representatives. Many observers foresee at least a partial shift in power, with the Democratic party regaining control of one or both of the houses of Congress. If that happens, the election could set the stage for some significant changes in US science policy.

It is simplistic to regard the Democrats as more 'pro-science' than the Republicans. It is true that academics usually lean to the left, and that scientists have a long history of liberal activism. But Republicans have a strong track record in boosting funding for science, leading the push to double the budget of the National Institutes of Health and, more recently, proposing an increase for the physical sciences in the federal budget for the next fiscal year (see Nature 439, 644-645; 2006). Slogans such as the 'Republican war on science', meant to sum up a host of perceived abuses, do not do justice to the complex relationship between science and each of the two major political parties.

Still, the Republican administration of President George W. Bush has come under plenty of fire for its approach to science. Groups such as the Union of Concerned Scientists have charged it with delaying or tampering with scientific decisions. Prominent examplesinclude the Food and Drug Administration's reluctance to make a decision on the Plan B emergency contraceptive pill, against the advice of its own advisory panels, and White House officials editing parts of an Environmental Protection Agency document dealing with climate change.

Now the opportunity arises for scientific groups to start concen- trating on how to build better relations with the next administration, which will be elected in two years. As a former adviser to President Clinton suggests on page 751 , there are some concrete steps that scientists can take if they wish to influence how the next president approaches science.

Researchers should be considering how their own areas of expertise - be it biosecurity, chemical physics or environmental toxicology - can most effectively be incorporated into national policy. They should identify who obtains positions and chairs on relevant congressional committees and open a dialogue with them. They can also develop relationships with other groups with whom they have common interests.

The United States is blessed with an immensely deep reservoir of scientific talent that can, all else being equal, be applied to furthering the national interest. Over the past few years, some communities of scientists have felt that their input is unwelcome in Washington. Specialists in embryonic stem-cell research, for example, have been denied federal funding for work on any new cell lines. Many have resorted to parallel, administratively awkward private or statefunded laboratories; some have even moved abroad. Weapons physicists and specialists in non-proliferation have lost much of their influence. Climate scientists with mainstream views on global warming have been accused of political bias. These are only a few of the areas in which researchers are feeling frustrated by the current administration and its supporters in Congress.

Political leaders will always seek to use science to further their own ends. The political reception to last week's Lancet paper estimating that some 650,000 Iraqi civilians have died as a result of the US-led invasion (see page 728) is just one example of the impossibility of a clean divide between science and politics. But US scientists should now be working constructively to develop an improved relationship with the new Congress - whatever its political composition. 